\title{
Factors Influencing the Enhancement of Energy Efficiency in the Oil and Gas Industry
}

\author{
Silvian Suditu, ${ }^{1,}$, Monica Emanuela Stoica $^{1}$, and Tudora Cristescu $^{1}$ \\ ${ }^{1}$ University Petroleum-Gas of Ploieşti, Drilling, Extraction and Transport of Hydrocarbons \\ Department, No. 39 Bucuresti Blvd., Ploiesti, Romania
}

\begin{abstract}
In Romania, major focus and interest are currently expressed for the energy strategies domain. The increase of the energetic efficiency is therefore a main concern for the authorities. In the current paper the main factors which are leading to the increase of this energetic efficiency are highlighted. These are: CHP (Combined Heat Power), combined cycles, the use of RER (reusable energy resources). The article also contains a classification of the RES (secondary energy resources) as function of the thermodynamic agent nature and/or its thermodynamic state. The theory and concepts are strengthened with relevant examples which have direct applicability in the oil and gas industry.
\end{abstract}

\section{Introduction}

Energy has been and will be the priority subject of a society. Be it for the well-being of the population or for economic growth/development, energy is indispensable. It can be used directly or indirectly, i.e., by saving or reusing it, which leads to the reduction of chemical and thermal pollution.

In 1992 environmental experts from over 200 countries gathered in Rio de Janeiro in order to provide solutions to the global environmental crises that society has been facing. On that occasion it was acknowledged that the climate system was a common resource whose stability could be affected by the emissions of carbon dioxide and greenhouse gases.

In 1994 Romania ratified the United Nations Framework Convention on Climate Change. Thus, Romania clearly expressed not only its concern about global climate change but also its firm intention to meet its commitments under the Convention.

In Kyoto, Japan, between 1-11 December 1997, 161 countries concluded an agreement called the "Kyoto Protocol", which sets the terms and rules for reducing greenhouse-gas emissions [1-2].

Energy issues have had significant inflence upon the dynamics of Romanian legislation.

Law on Energy Efficiency 121/2014 aims at creating the legal framework for the development and implementation of the national energy efficiency policy in order to achieve the national energy efficiency target. Energy efficiency policy measures apply across the entire chain: primary resources, production, distribution, supply, transport and final consumption. A national target of reducing energy consumption by $19 \%$ until 2020 has been set.

\footnotetext{
"Corresponding author: silviusuditu@yahoo.com
} 
As regards energy efficiency policy, some of the most important aspects refer to:

- Promoting energy efficiency mechanisms and financial instruments for energy saving;

- Education and awareness of final consumers regarding the importance and benefits of implementing energy efficiency improvement measures;

- Promoting fundamental and applied research in the field of efficient energy use;

- Introducing high energy efficiency technologies, modern measurement and control systems as well as energy management systems for continual energy efficiency assessment and monitoring, and energy consumption forecasting;

- Reducing the environmental impact of industrial activities and producing, transporting, distributing and consuming all forms of energy;

- Promoting the use of energetically efficient equipment and renewable energy sources by end-users;

- Applying the modern principles of energy management [3-4].

The main energy-saving means that specialists use is energy balance, which allows both qualitative and quantitative analyses regarding the manner in which fuel and all forms of energy are used within the limits of a determined system [5-9].

In the authors' view, there are several ways to increase fuel efficiency consumption, such as:

- combined cycles;

- CHP (Combined Heat and Power).

Another aspect concerns effective ways of energy recycling. For this purpose, the following steps need to be taken:

- evaluation of secondary energy sources (SES);

- use of renewable energy sources (RES).

\section{Secondary energy sources. Renewable energy sources}

The secondary energy sources (SES) of a process or aggregate represent all forms of energy not used in the respective process or technological aggregate. SES are the result of a primary technological process, as its by-products, being part of the energy losses of the process or aggregate. The amount of energy of SES that is not recovered dissipates in the environment.

The definition and calculation of SES is made for a reference contour which includes the part of the installation or subassembly envisaged. The reasons for the occurrence of SES are the energetic imperfections of the processes that take place within the contour considered. The higher the energy of SES, the more the processes in the contour take place with lower energy yields. For technical and economic reasons only a part of the resulting SES can be used.

Renewable energy sources (RES) are the part of the secondary energy sources that can be recovered in the context of economic efficiency. This part depends on the development stage of the technology in question as well as on the costs of energy and materials used [10-11].

\subsection{The effects of recovering secondary energy sources on an oil production plant}

The effects of recovering secondary energy sources on an oil production plant are not only technical, but also economic and environmental. In technical terms, the design and fitting of recovery systems directly into the technological flow contributes to the modernization of oil transport, storage and treatment and allow the implementation of energy-efficient technologies. As a result, these technological aspects can be optimized. From an economic point of view, energy is thus saved, which helps reduce energy consumption for the contour considered (oil production plant, oil storage and treatment parks or other related systems) and save conventional fuel. The ecological aspect of recovering secondary energy sources relates 
to the reduction of heat emissions, which represent an imminent danger of destroying the planet's ecological balance [12].

\subsection{Criteria for measuring the efficiency of recovering secondary energy sources on an oil production plant}

The efficiency of recovering secondary energy sources on an oil production plant is measured taking into account technological, energy, ecological and economic criteria. As far as technological criteria are concerned, the recovery solutions lead to the optimization of oil transport, storage and treatment processes. The main energy indicator that shows the efficiency of recovery solutions is conventional fuel saving.

Ecological efficiency is determined by taking into account the reduction of thermal pollution. Also, the EU environmental norms concerning environment protection have provisions regarding both air quality and taxes on air pollution. Economic efficiency is determined by specific calculations which take into account cost, benefit as well as costeffectiveness. Table 1 shows the evaluation of secondary energy sources (SES) based on the thermodynamic agent type and / or its thermodynamic state and the use of renewable energy sources (RES), depending on the development stage of the technology involved [12].

Table 1. Identification of secondary energy sources and of ways of reusing them on an oil rig [12].

\begin{tabular}{|c|c|c|}
\hline $\begin{array}{l}\text { Secondary energy } \\
\text { sources (SES) } \\
\text { Renewable energy } \\
\text { sources (RES) }\end{array}$ & $\begin{array}{l}\text { Thermodynamic agent } \\
\text { type and state }\end{array}$ & $\begin{array}{l}\text { Ways of reusing SES on an oil } \\
\text { production plant }\end{array}$ \\
\hline \multirow{4}{*}{$\begin{array}{l}\text { Recovery of heat } \\
\text { contained in combustion } \\
\text { gases }\end{array}$} & \multirow{2}{*}{$\begin{array}{l}\text { With temperatures up to } \\
250^{\circ} \mathrm{C} \text { due to } \\
\text { combustion processes } \\
\text { taking place in steam or } \\
\text { hot water generating } \\
\text { units }\end{array}$} & $\begin{array}{l}\text { For technological purposes: combustion } \\
\text { air preheating, fuel preheating, heating } \\
\text { some petroleum products, water } \\
\text { preheating }\end{array}$ \\
\hline & & $\begin{array}{l}\text { For thermal purposes: preparing hot } \\
\text { water for domestic purposes or space } \\
\text { heating; air heating for indoor air } \\
\text { conditioning units (living quarters or } \\
\text { greenhouses) }\end{array}$ \\
\hline & \multirow{2}{*}{$\begin{array}{l}\text { With temperatures } \\
\text { between } 250{ }^{\circ} \mathrm{C} \text { and } 400 \\
{ }^{\circ} \mathrm{C} \text {, coming from } \\
\text { internal combustion } \\
\text { engines }\end{array}$} & $\begin{array}{l}\text { For technological purposes: preheating } \\
\text { combustion air, heating some oil } \\
\text { products, producing water vapor, } \\
\text { preheating water }\end{array}$ \\
\hline & & $\begin{array}{l}\text { For thermal purposes: preparation of hot } \\
\text { water for domestic use or for heating } \\
\text { workspace and living quarters }\end{array}$ \\
\hline \multirow{2}{*}{$\begin{array}{lrr}\text { Recovery of } & \text { heat } \\
\text { contained in the } & \text { gases } \\
\text { resulting from } & \text { oil } \\
\text { separation } & & \end{array}$} & & $\begin{array}{l}\text { For technological purposes: preheating } \\
\text { the air necessary for combustion; heating } \\
\text { some oil fluids }\end{array}$ \\
\hline & & $\begin{array}{l}\text { For thermal purposes: preparation of hot } \\
\text { water for domestic use }\end{array}$ \\
\hline \multirow[b]{2}{*}{ Use of used steam } & \multirow[b]{2}{*}{$\begin{array}{l}\text { Coming from steam- } \\
\text { driven pumps or } \\
\text { compressors }\end{array}$} & $\begin{array}{l}\text { For technological purposes: heating some } \\
\text { petroleum products, preheating water }\end{array}$ \\
\hline & & $\begin{array}{l}\text { For thermal purposes: heating the water } \\
\text { in the water supply system for buildings } \\
\text { or neighboring consumers; heating air for } \\
\text { indoor air conditioning units }\end{array}$ \\
\hline
\end{tabular}




\begin{tabular}{|c|c|c|}
\hline & $\begin{array}{l}\text { Coming from the } \\
\text { continuous purge of hot } \\
\text { water or steam } \\
\text { generators }\end{array}$ & $\begin{array}{l}\text { For technological purposes: preheating } \\
\text { feed water before its chemical treatment } \\
\text { and degassing }\end{array}$ \\
\hline \multirow{2}{*}{$\begin{array}{l}\text { Use of hot water (or } \\
\text { condensate) coming from } \\
\text { the heating systems of oil } \\
\text { storage and treatment } \\
\text { facilities }\end{array}$} & & $\begin{array}{l}\text { For technological purposes: preheating of } \\
\text { some petroleum products }\end{array}$ \\
\hline & & $\begin{array}{l}\text { For thermal purposes: preparation of hot } \\
\text { water for consumption }\end{array}$ \\
\hline \multirow{4}{*}{$\begin{array}{l}\text { Use of cooling water from } \\
\text { technological installations } \\
\text { or from internal } \\
\text { combustion engines }\end{array}$} & \multirow{2}{*}{$\begin{array}{l}\text { Water with } \\
\text { temperatures between } \\
25^{\circ} \mathrm{C} \text { and } 50^{\circ} \mathrm{C}\end{array}$} & $\begin{array}{l}\text { For technological purposes: preheating } \\
\text { added water for hot water or steam } \\
\text { generators }\end{array}$ \\
\hline & & $\begin{array}{l}\text { For thermal purposes: preparing hot } \\
\text { water for domestic use, heating indoor air }\end{array}$ \\
\hline & \multirow{2}{*}{$\begin{array}{l}\text { Water with } \\
\text { temperatures between } \\
50^{\circ} \mathrm{C} \text { and } 100^{\circ} \mathrm{C}\end{array}$} & $\begin{array}{l}\text { For technological purposes: preheating } \\
\text { added water for hot water or steam } \\
\text { generators and preheating oil fluids }\end{array}$ \\
\hline & & $\begin{array}{l}\text { For thermal purposes: preparing hot } \\
\text { water, heating indoor air }\end{array}$ \\
\hline $\begin{array}{l}\text { Use of resulting } \\
\text { combustible SES from oil } \\
\text { treatment plants }\end{array}$ & & $\begin{array}{l}\text { For technological purposes: combustible } \\
\text { gas use in the combustion processes } \\
\text { taking place in an oil rig's thermal } \\
\text { system; their delivery to various } \\
\text { beneficiaries }\end{array}$ \\
\hline Use of hot oil & & $\begin{array}{l}\text { For technological purposes: heating } \\
\text { some oil fluids }\end{array}$ \\
\hline
\end{tabular}

\section{Cogeneration}

Cogeneration is one of the most economical technologies aimed at reducing greenhouse gas (GHG) emissions, along with the use of renewable energies.

Cogeneration is the combined and simultaneous production of mechanical work and heat, starting from a single source of primary energy. In the other countries the term COMBINED HEAT AND POWER (CHP) is used.

Energy efficiency is given by global yield, which is superior to separate production [13]:

$$
\eta_{g}=(Q+E) / W
$$

where:

$\mathrm{Q}$ - heat (MWh);

E - electricity (MWh);

$\mathrm{W}$ - energy equivalent of fuel consumption (MWh).

In general, the combination of economic and ecological benefits is to be achieved by using cogeneration installations, where the reduction of conventional fuel consumption leads to the reduction of noxious emissions $\left(\mathrm{CO}_{2}, \mathrm{CO}, \mathrm{NOx}\right.$, etc. $)$ [14-15].

Trigeneration is also used because it produces three forms of energy - electricity, heating and cooling - through one process.

Cogeneration can take place in a steam turbine power plant or in a gas turbine installation. 


\section{Combination of two thermal cycles}

The combination of two thermal cycles is aimed at obtaining energy and economic benefits by:

- achieving a mixed cycle yield, superior to that of component installations, when they would work individually;

- integrating energy and technological facilities to enable the use of low calorific or sulfurrich fuels;

- increased maneuverability of installations;

- reducing environmental pollution.

The combination of cycles is based on the use of the thermodynamic cascade. The heat released from a high temperature cycle is used in the lower temperature cycle.

Figure 1 shows the diagram of an open-circuit gas turbine installation and steam generator with no additional combustion.

It includes the following equipment:

- $\mathrm{C}$ - air compressor;

- $\mathrm{CA}$ - combustion chamber;

- $\quad$ TG - gas turbine;

- $\mathrm{GE} 1, \mathrm{GE} 2$ - power generators;

- $\quad \mathrm{RC}$ - heat recovery unit;

- GA - water vapor generator (steam generator);

- TA - steam turbine;

- Co - condenser;

- PA - power pump.

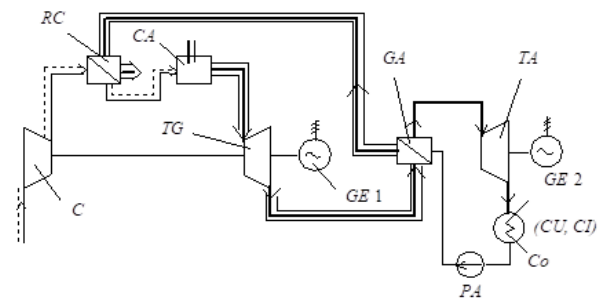

Fig. 1. Diagram of a cogeneration plant with gas turbine installation and steam turbine installation [13].

\section{Case studies}

\subsection{Probe gas combustion}

In the process of probe gas combustion having the following volume composition (Table 2):

Table 2. Probe gas composition.

\begin{tabular}{|c|c|c|c|c|c|c|c|}
\hline Components & $\begin{array}{c}\text { Methane, } \\
\mathrm{CH}_{4}\end{array}$ & $\begin{array}{c}\text { Ethane, } \\
\mathrm{C}_{2} \mathrm{H}_{6}\end{array}$ & $\begin{array}{c}\text { Propane, } \\
\mathrm{C}_{3} \mathrm{H}_{8}\end{array}$ & $\begin{array}{c}\text { Butane, } \\
\mathrm{C}_{4} \mathrm{H}_{10}\end{array}$ & $\begin{array}{c}\text { Pentane, } \\
\mathrm{C}_{5} \mathrm{H}_{12}\end{array}$ & $\begin{array}{c}\text { Hexane, } \\
\mathrm{C}_{6} \mathrm{H}_{14}\end{array}$ & $\begin{array}{c}\text { Carbon } \\
\text { Dioxide } \\
\mathrm{CO}_{2}\end{array}$ \\
\hline$\%$ & 69 & 9.24 & 6.23 & 3.46 & 1.1 & 1.77 & 9.2 \\
\hline
\end{tabular}

A volumetric composition of the combustion gases is shown in Table 3.

Table 3. Volumetric composition of combustion gases. 


\begin{tabular}{|c|c|c|c|c|c|}
\hline Components & $\begin{array}{c}\text { Carbon Dioxide, } \\
\mathrm{CO}_{2}\end{array}$ & $\begin{array}{c}\text { Water, } \\
\mathrm{H}_{2} \mathrm{O}\end{array}$ & $\begin{array}{c}\text { Sulphur dioxide } \\
\mathrm{SO}_{2}\end{array}$ & $\begin{array}{c}\text { Oxygen, } \\
\mathrm{O}_{2}\end{array}$ & $\begin{array}{c}\text { Azote, } \\
\mathrm{N}_{2}\end{array}$ \\
\hline$\%$ & 10.2 & 15.6 & 0 & 1.7 & 72.5 \\
\hline
\end{tabular}

It is believed that a gaseous fuel flow of $362 \mathrm{~m}^{3} \mathrm{~N} / \mathrm{h}$ is consumed. Combustion gases are discharged from the steam generator at a temperature of $252^{\circ} \mathrm{C}$ and from the heat recovery unit - at a temperature of $92^{\circ} \mathrm{C}$. The heat recovery unit has $100 \%$ efficiency. The running time of the steam generator and the heat recovery unit is $5000 \mathrm{~h} /$ year.

Thus:

- A recovered flow of $321.8 \mathrm{~kW}$, which means a conventional fuel flow of $39.52 \mathrm{kgcc} / \mathrm{h}$;

- $1382.3 \mathrm{Gcal}$ is recovered throughout a year.

\subsection{Thermo- energy balance for a gas turbine installation.}

For a gas turbine cogeneration plant (Figure 2), the energy balance and the output at the terminals of the generator will be carried out. The balance will be carried out for the rated load of $10 \mathrm{MW}$, for which the following data are known:

- fuel consumption: $\mathrm{B}=0.95 \mathrm{~m}^{3} \mathrm{~N} / \mathrm{s}$;

- low fuel calorific value: $\mathrm{H}_{\mathrm{i}}=35000 \mathrm{~kJ} / \mathrm{m}^{3} \mathrm{~N}$;

- mechanical efficiency: $\eta_{\mathrm{m}}=0.99$;

- generator yield: $\eta_{\mathrm{g}}=0.97$;

- exhaust gas temperature: $\mathrm{t}_{\mathrm{g}}=350{ }^{\circ} \mathrm{C}$;

- initial temperature of cooling water: $\mathrm{t}_{\mathrm{i}}=14^{\circ} \mathrm{C}$;

- final temperature of cooling water: $\mathrm{t}_{\mathrm{f}}=49^{\circ} \mathrm{C}$;

- cooling water flow: $\dot{\mathrm{m}}_{\mathrm{R}}=15 \mathrm{~kg} / \mathrm{s}$;

- carbon oxide content: $\mathrm{CO}=1 \%$;

- total volume of exhaust gas output: $\mathrm{V}_{\mathrm{g}}=20 \mathrm{~m}^{3} \mathrm{~N} / \mathrm{s}$;

- air volume: $\mathrm{V}_{\text {aer }}=8.7 \mathrm{~m}^{3} \mathrm{~N} / \mathrm{s}$;

- average specific heat of combustion gases: $\mathrm{c}_{\mathrm{pg}}=1.46 \mathrm{~kJ} / \mathrm{m}^{3}{ }_{\mathrm{N}}^{\circ} \mathrm{C}$;

- average specific fuel heat: $\mathrm{c}_{\mathrm{pB}}=1.55 \mathrm{~kJ} / \mathrm{m}^{3}{ }_{\mathrm{N}}{ }^{\circ} \mathrm{C}$;

- average specific heat of air: $c_{a e r}=1.29 \mathrm{~kJ} / \mathrm{m}^{3}{ }_{\mathrm{N}}^{\circ} \mathrm{C}$ [16];

- average temperature of engine walls: $\mathrm{t}_{\mathrm{p}}=50^{\circ} \mathrm{C}$;

- engine area: $\mathrm{S}_{\mathrm{m}}=6 \mathrm{~m}^{2}$;

- global heat exchange coefficient by radiation and convection: $\alpha_{\mathrm{rc}}=9 \mathrm{~kW} / \mathrm{m}^{2 \circ} \mathrm{C}$.

It is known that the energy consumed by the compressor is $\chi=35 \%$ out of the one produced by the turbine.

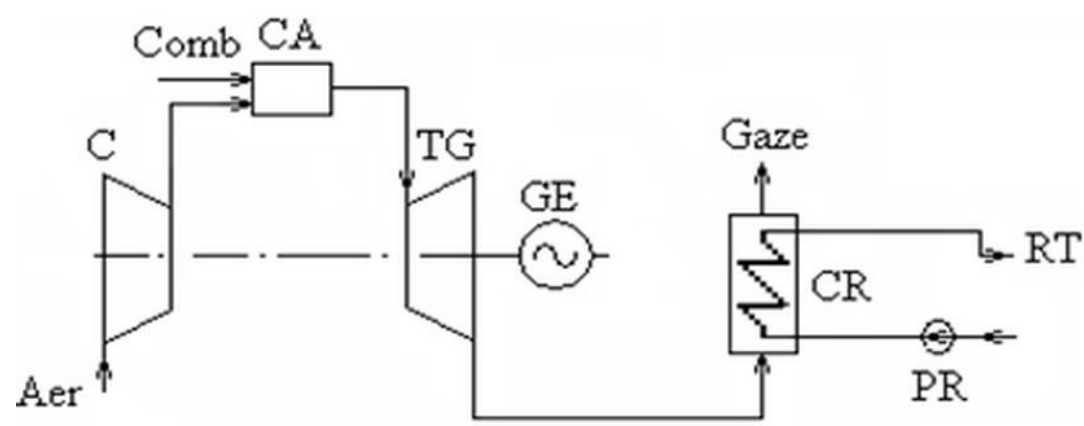

Fig. 2. Gas turbine cogeneration plant. 
The designations in the figure have the following significance:

- C - compressor;

- CA - combustion chamber;

- GE - electric generator;

- PR - network pump;

- RT - thermal networks;

- $\mathrm{CR}$ - recovery boiler;

- TG - gas turbine.

Table 4 shows all the results obtained, i.e., the heat input and the heat output, respectively. The graphical representation of the balance, in the form of a Sankey diagram, is shown in Figure 3.

Table 4. Energy flow for a gas turbine installation.

\begin{tabular}{|c|c|c|c|c|c|}
\hline Heat Input & $\mathrm{kW}$ & $\%$ & Heat Output & $\mathrm{kW}$ & $\%$ \\
\hline $\mathrm{Q}_{\mathrm{B}}$ & 33272 & 99.49 & $\mathrm{Q}_{\mathrm{u}}$ & 10000 & 29.9 \\
\hline $\mathrm{Q}_{\text {aer }}$ & 168.345 & 0.51 & $\mathrm{Q}_{\mathrm{ga}}$ & 10220 & 30.56 \\
\hline & & & $\mathrm{Q}_{\mathrm{c}}$ & 5384.6 & 16.1 \\
\hline & & & $\mathrm{Q}_{\mathrm{ch}}$ & 2523 & 7.55 \\
\hline & & & $\mathrm{Q}_{\mathrm{R}}$ & 2194.5 & 6.56 \\
\hline & & & $\mathrm{Q}_{\mathrm{rc}}$ & 1890 & 5.65 \\
\hline & & & $\Delta \mathrm{Q}$ & 825.245 & 2.47 \\
\hline & & & $\mathrm{Q}_{\mathrm{g}}$ & 303 & 0.91 \\
\hline & & & $\mathrm{Q}_{\mathrm{m}}$ & 100 & 0.30 \\
\hline Total Heat Input & 33440.345 & 100 & Total Heat Output & 33440.345 & 100 \\
\hline & & & & & \\
\hline
\end{tabular}

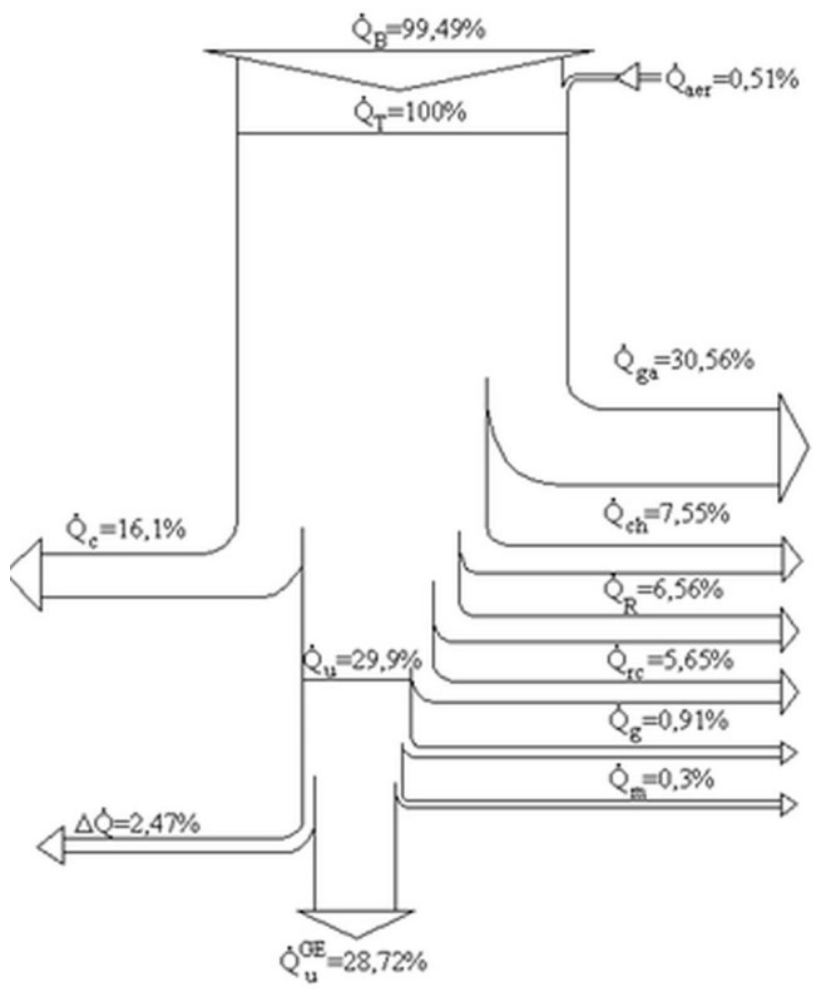

Fig. 3. Sankey diagram for a gas turbine installation. 


\subsection{Thermal energy balance at a cogeneration plant with steam turbines.}

For a steam turbine cogeneration plant (Figure 4), with natural gas fuel and the flue gas flow $\mathrm{Q}_{\mathrm{ga}}=10210 \mathrm{~kW}$, the energy balance will be done using a Sankey diagram. The following data are known:

- $\quad$ steam generator yield: $\eta_{\mathrm{GA}}=0.92$;

- piping efficiency: $\eta_{\mathrm{cd}}=0.99$;

- thermal cycle yield: $\eta_{\mathrm{t}}=0.3465$;

- the mechanical efficiency of the turbine: $\eta_{\mathrm{m}}=0.98$;

- electric generator efficiency: $\eta_{\mathrm{GE}}=0.985$;

- consumption of domestic services: $\varepsilon=0.05$;

- main transformer output: $\eta_{\text {tr }}=0.99$.

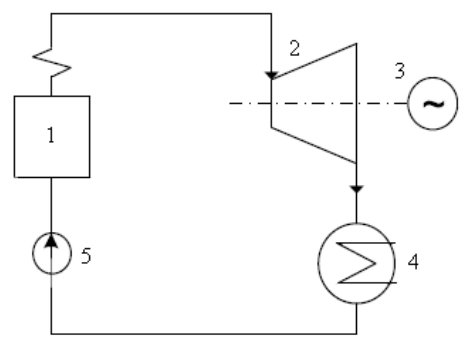

Fig. 4. Diagram of a steam turbine installation (1 - boiler; 2 - steam turbine; 3 - electric generator; 4 condenser; 5 - power pump).

Figure 5 shows the Sankey diagram corresponding to the system, whereas Table 5 shows the thermal flows going in and out of the system.

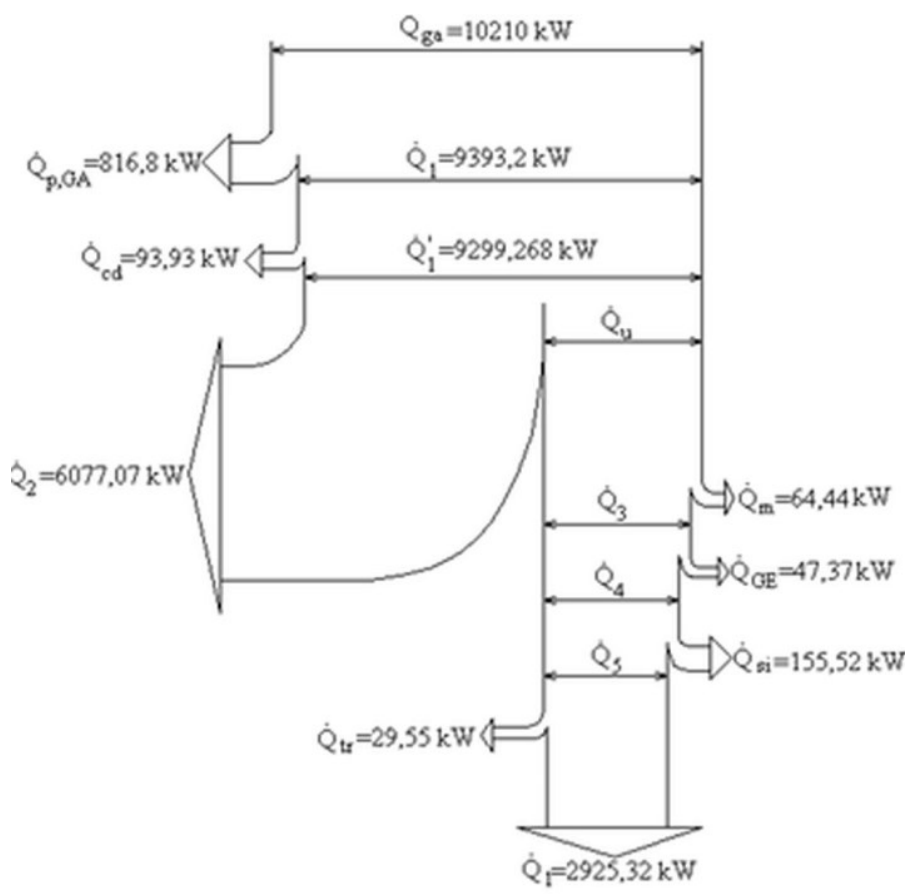

Fig. 5. Sankey diagram for the steam turbine installation. 
Table 5. Energy flows for a steam turbine installation.

\begin{tabular}{|c|c|c|c|}
\hline Thermal flow input & $\mathrm{kW}$ & Thermal flow output & $\mathrm{kW}$ \\
\hline $\mathrm{Q}_{\mathrm{ga}}$ & 10210 & $\mathrm{Q}_{\mathrm{p}, \mathrm{GA}}$ & 816.8 \\
\hline & & $\mathrm{Q}_{\mathrm{cd}}$ & 93.93 \\
\hline & & $\mathrm{Q}_{2}$ & 6077.07 \\
\hline & & $\mathrm{Q}_{\mathrm{m}}$ & 64.44 \\
\hline & & $\mathrm{Q}_{\mathrm{GE}}$ & 47.37 \\
\hline & & $\mathrm{Q}_{\mathrm{SI}}$ & 155.52 \\
\hline & & $\mathrm{Q}_{\mathrm{tr}}$ & 29.55 \\
\hline & & $\mathrm{Q}_{1}$ & 2925.32 \\
\hline Total thermal flow input & 10210 & Total thermal output & 10210 \\
\hline
\end{tabular}

\section{Conclusions}

The evaluation of secondary and renewable energy sources on an oil production plant allows the identification of various ways to increase the energy efficiency of oil transport, storage and treatment processes. Thus, solutions to reduce chemical and thermal pollution of the environment can also be provided. It is considered that the most coherent and pragmatic method of energy analysis, through which the ways of increasing energy efficiency are identified, is the periodic drawing of energy balances. Cogeneration and trigeneration are appropriate solutions that meet the demand for electrical and thermal and cooling energy, respectively, and reduce fuel consumption, which, in any similar situation, also meets the requirements of environmental protection.

\section{References}

1. http://www.consilium.europa.eu (accessed 22.03.2019)

2. http://www.mmediu.ro (accessed 22.03.2019)

3. Parliament of Romania, Legea 121/2014 privind eficienţa energetica (Monitorul Oficial al României, Bucharest, 2014)

4. Romanian Association for Standardization, SR EN ISO 50001:2011 Sisteme de management al energiei. Cerinţe şi ghid de utilizare (ASRO, Bucharest, 2011)

5. Parliament of Romania, Ghid de elaborare şi analiză a bilanturilor energetice (Monitorul oficial al României, Bucharest, 2003)

6. ICEMENERG, Normativ privind întocmirea şi analiza bilanţurilor energetice, (Bucharest, 1995)

7. Conpet SA, Servicii privind elaborarea bilanțului termoenergetic din Stația țiței Băicoi, (Conpet, Ploiești, 2015)

8. Conpet SA, Analiză energetică pentru implementarea sistemului de management al energiei în conformitate cu ISO 50001:2011, (Conpet, Ploiești, 2014)

9. C. Raducanu, R. Patrascu, E. Minciuc, Bilanturi termoenergetice (Universitatea Politehnica din Bucuresti, Bucharest, 2004)

10. V. Athanasovici, Resurse energetice secundare-Resurse energetice refolosibile (Editura Tehnica, Bucharest, 1989)

11. A. Badea, M. Stan, R. Patrascu, H. Necula, G. Darie, P. Blaga, L. Mihaescu, P. Ulmeanu, Bazele termoenergeticii (Universitatatea Politehnica din Bucuresti, Bucharest, 2003)

12. T. Cristescu, M. Patarlageanu, S. Suditu, M. G. Popescu, Proceedings of the 8th International Conference, Târgu Jiu (2002)

13. T. Cristescu, Termotehnica (Editura Universităţii din Ploieşti, Ploiești, 2009)

14. R. Patrascu, Proceedings of the National Colloquium Metode, instalaţii şi echipamente pentru măsurarea, gestiunea şi conservarea energiei, SOCER Craiova (1997)

15. M. Gambinia, M. Vellinia, Energy Procedia 81430 - 439 (2015)

16. K. Raznjevic, Tabele şi diagrame termodinamice (Editura Tehnica, Bucharest, 1978) 